\section{International Scientific Journal Theoretical \& Applied Science}

Alexander Sergueevich Semenov Ph.D., CEO, Deep Dive Research Group, Russian Federation semyonov1980@mail.ru

Vladimir Vladimirovich Bulat expert,

Deep Dive Research Group, Russian Federation buen_dia@mail.ru

SECTION 12. Geology. Anthropology.

Archaeology.

\title{
CORDED WARE CULTURES BETWEEN VALDAI AND ALTAI-BAIKAL REGIONS: ON THE AREAL OF DISTRIBUTION OF Y-DNA HAPLOGROUP R1A1-M17 IN NEOLITHIC EURASIA
}

\author{
Abstract: The paper deals with the spread of Corded Ware Cultures in the Western and Eastern Eurasia. \\ According to the last genetic data (Rlal-M17 in Neolithic Baikal area) the hypothesis on their relation is \\ proposed. \\ Key words: Neolithic, haplogroup, Corded Ware, Rla1-M17 (M-198). \\ Language: Russian \\ Citation: Semenov AS, Bulat VV (2016) CORDED WARE CULTURES BETWEEN VALDAI AND ALTAI- \\ BAIKAL REGIONS: ON THE AREAL OF DISTRIBUTION OF Y-DNA HAPLOGROUP R1A1-M17 IN \\ NEOLITHIC EURASIA. ISJ Theoretical \& Applied Science, 09 (41): 166-172. \\ Soi: http://s-o-i.org/1.1/TAS-09-41-29 Doi: crossef http://dx.doi.org/10.15863/TAS.2016.09.41.29

\section{КУЛЬТУРЫ ШНУРОВОЙ КЕРАМИКИ ОТ ВАЛДАЯ ДО АЛТАЯ И БАЙКАЛА: ОБ АРЕАЛЕ РАСПРОСТРАНЕНИЯ Ү-ГАПЛОГРУППЫ R1А1-М17 В НЕОЛИТИЧЕСКОЙ ЕВРАЗИИ} \\ Аннотация: В данной статье рассматриваются культуры шнуровой керамики Востока Евразии. На \\ основании последних генетических данных (обнаружение Rlal-M17 в неолите Прибайкалья) делается \\ предположение о родстве культур шнуровой керамики Востока и Запада Евразии и анализируются \\ возможные культурные и переселенческие миграции. \\ Ключевые слова: гаплогруппа, неолит, шнуровая керамика, Rla1-M17 (M-198).
}

\section{Introduction}

С недавних пор обнаружено, что одним из первых в мире очагом развития гончарного ремесла и появления глиняной посуды был регион Дальнего Востока, в том числе японская культура Дземон, самые ранние образцы керамики которой датируются XIII тысячелетием до н.э. [1] (хотя другим, естественно, не менее важным центром неолитической революции остается Ближний Восток [2]). Влияние Дземона распространялось на регион Приамурья, где в это время существует громатухинская культура и немного более поздняя новопетровская [3, с 6368], из которых керамика первой примерно на 1000 лет моложе керамики Дземона, а в Приморье древнейшими памятниками с керамикой являются Черниговка (около 8770 года до н.э.), Устиновка-3 (около 8000 года до н.э.), Перевал (древнее 6300 лет до н.э.) [4]. Т.о. очевидно существование в XIII-VII тысячелетиях до н.э. крупного дальневосточного очага ISPC Global Applied Research, Harrisburg, USA неолитической революции, и вопрос о пределах влияния данного очага, который, по многим данным, древнее ближневосточного, является интригующим вопросом истории неолита (поскольку иные очаги неолита либо вовсе не существуют, либо до сих пор не обнаружены). Вопрос очень важен, посколько именно в дальневосточных культурах имеются древнейшие образцы техники шнуровой керамики. Для истории же Запада одним из ключевых вопросов является происхождения и влияния культуры Европейской шнуровой керамики, устойчиво ассоциируемой с индоевропейскими языками и распростнанением Y-гаплогруппы R1a1-M17 (M198).

Materials and Methods

Прежде, чем искать аналоги дземоновской и громатухинской керамике в отдаленных регионах, следует обратить внимание на близлежащие регионы - в первую очередь на 
Китай, Корею и Сибирь. В китайской провинции Хунань в 1988 году было обнаружено самое древнее стационарное поселение человека в регионе - Пэнтоушань, которое вместе с поселением Башидань образует ранненеолитическую культуру Пэнтоушань, датируемую эпохой 7500-6100 лет до н.э. [5, p 63], но, по данным радиоуглеродного анализа, найденные здесь древнейшие остатки культурного риса датируются 8200-7800 гг. до н.э. [6, p 298]. Среди находок обнаружена шнуровая керамика, самая ранняя форма керамики, родственная культуре Дзёмон. Это последнее обстоятельство весьма существенно в качестве маркера культурных связей для поиска возможных влияний Дземона за пределами Восточной Азии в целом. Гончарное искусство корейской эпохи Чыльмун (3500-2000 лет до н.э.) проявляет сильное сходство с гончарной культурой Дзёмон [7, p 137]. Правда, первые гончарные изделия на Корейском полуострове датируются 8000 годом до н.э., однако, поскольку миграционные влияния происходили с севера, не исключено, что здесь также влияние Приамурья и Приморья. Наконец, в Сибири в конце IV начале III тысячелетия до н.э. обнаруживаем белькачинскую неолитическую культуру: «белькачинцы свои глиняные сосуды изготавливали способом выколачивания. При формовке сосуда применяли деревянную колотушку, у которой рабочая часть была обмотана крученым шнурком. Четкие оттиски последнего оставались на внешней поверхности сосудов. В научной литературе сосуды, изготовленные колотушкой с обмотанным шнурком, называют шнуровой керамикой. Остатки шнуровой керамики найдены не только на территории Якутии, но и на Дальнем Востоке и, даже, в Северной Америке. Исходя из этого, исследователи предполагают, что носители белькачинской культуры могут быть родоначальниками некоторых индейских племен Северной Америки» [8]. Белькачинская культура датируется промежутком $4100 \pm 300-2160 \pm 150$ до н.э. [9].

Описав целый круг культур со шнуровой керамикой, продолжающих технику, наработанную еще в Дземоне, мы не можем обойти стороной вопрос об их вероятной этноязыковой принадлежности. Точку зрения на принадлежность самой культуры Дземон протоайнским племенам эпохи неолита в настоящее время является общепринятой $[10 ; 11]$. Не стоит исключать, что появление керамики типа Дземон в китайской провинции Хунань связано с миграцией каких-либо айноязычных групп. Громатухинская и ноповетровская культуры относятся к региону обитания современных нивхов, хотя, несмотря на то, что нивхи, вполне возможно, один из самых древнейших слоев населения Дальнего Востока, не вполне ясен вопрос о времени их первоначального расселения на Нижнем Амуре. Этот вопрос еще требует прояснения.

Ситуация уже более точна с языком белькачинской культуры. Если углубиться в вопрос о языках белькачинской и родственных ей культур бассейна Лены и прилегающих районов, то гипотеза о связи белькачинской культуры с какими-либо индейскими племенами Северной Америки может рассматриваться в контексте т.н. дене-енисейской гипотезы - сопоставления енисейских языков совр. Среднего Енисея и целой языковой семьи Северной Америки, занимающей самые крайние северо-западные регионы, что может указывать на относительно недавнее появление денеязычных племен и синхронизацию их появления с временами существования белькачинской культуры. Если мы принимаем гипотезу о денеязычии неолитического населения Якутии, отличного в этом отношении от последующих слоев юкагирского и эвенкийского [12, с 70-71], а также ассоциируем денеязычные племена с палеоенисейскими культурами централноазиатского происхождения, то оказываемся в ареале сложных миграций племен неолитических и мезолитических культур зарзийского происхождения, охватывавших огромные пространства от Днепра до Южной Индии и Енисея.

Если западнее Енисея даже реликтов денеенисейской языковой общности не осталось, то «восточный фланг» дене-енисейцев обозначен реально существующей в наше время языковой семьей на-дене, включающей две ветви: тлинкитский язык и атапаскские языки [13]. Карта языковых семей и макросемей доколумбовой должна была выглядеть следующим образом: 


\begin{tabular}{|c|c|c|c|c|c|c|}
\hline Impact Factor: & $\begin{array}{l}\text { ISRA (India) } \\
\text { ISI (Dubai, UAE } \\
\text { GIF (Australia) } \\
\text { JIF }\end{array}$ & $\begin{array}{l}=1.344 \\
=0.829 \\
=0.564 \\
=1.500\end{array}$ & $\begin{array}{l}\text { SIS (USA) } \\
\text { PИНЦ (Russia) } \\
\text { ESJI (KZ) } \\
\text { SJIF (Morocco) }\end{array}$ & $\begin{array}{l}=0.912 \\
=0.234 \\
=1.042 \\
=2.031\end{array}$ & $\begin{array}{l}\text { ICV (Poland) } \\
\text { PIF (India) } \\
\text { IBI (India) }\end{array}$ & $\begin{array}{l}=6.630 \\
=1.940 \\
=4.260\end{array}$ \\
\hline
\end{tabular}

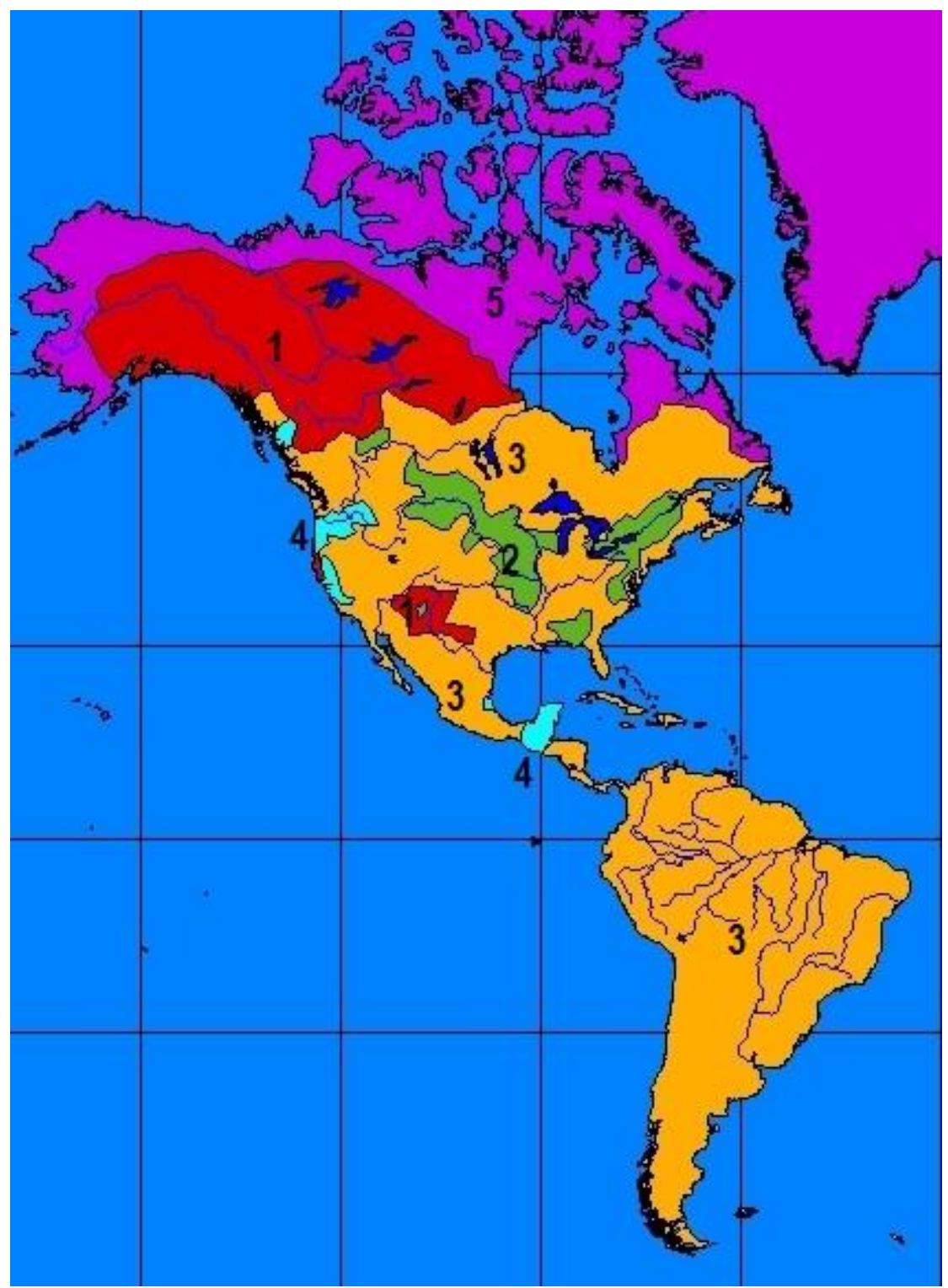

Рисунок 1 - Карта (В.В.Булат) вероятного расселения языковых семей и макросемей Доколумбовой Америки: 1 - семья на-дене, 2 - семья хока-сиу, 3 - америндская макросемья, 4 - фила пенути, 5 эскимосско-алеутская семья.

На данной карте видно, что хотя часть индейцев на-дене проникли почти до границ Месоамерики, основная часть семьи расселяется сейчас и расселялась в последние века на крайнем северо-западе Северной Америки, и их расположение приводит к мысли о миграции носителей языков на-дене, как о замыкающей переселения индейцев из Азии в Америку. Говорить о конкретных временных параметрах этой миграции сложнее. Специалисты, выдвинувшие дене-енисейскую гипотезу, датировали существование единого праязыка дене и енисейцев поздним мезолитом, что в условиях Сибири может растягиваться на несколько тысячелетий, смотря по тому, говорим ли мы о южных зонах раннего неолита, либо о северных регионах пережиточного мезолита.
Э.Вайда в 2012 году локализовал прародину дене-енисейцев между Амуром и Алданом [14], где после исчезновения палеолитической дюктайской культуры расселялись группы, относящиеся к сумнагинской мезолитической культуре [15, с 247-248] (маркером данной мигарции Вайда считает субклад Q1 Yхромосомной гаплогруппы). Соотношение сумнагинской и последующей сыалахской культуры - сложный вопрос. Сыалахская культура (V тысячелетие до н.э.) создана пришельцами из Забайкалья [16; 17, с 296], которые частично вытеснили, частично ассимилировали ее [там же]. Сыалахские племена, как и племена развившейся на основе сыалахской белькачинской культурой, говорили, 


\begin{tabular}{l|lr|ll|ll} 
& ISRA (India) & $=\mathbf{1 . 3 4 4}$ & SIS (USA) & $=\mathbf{0 . 9 1 2}$ & ICV (Poland) & $\mathbf{= 6 . 6 3 0}$ \\
Impact Factor: & ISI (Dubai, UAE) $=\mathbf{0 . 8 2 9}$ & PUHL (Russia) $=\mathbf{0 . 2 3 4}$ & PIF (India) & $=\mathbf{1 . 9 4 0}$ \\
& GIF (Australia) & $=\mathbf{0 . 5 6 4}$ & ESJI (KZ) & $=\mathbf{1 . 0 4 2}$ & IBI (India) & $=\mathbf{4 . 2 6 0}$
\end{tabular}

по всей видимости, на дене-енисейских языках $[18$, c 83$]$.

Поскольку есть все основания считать современных кетов-енисейцев, проживающих в Туруханском и Эвенкийском районах Красноярского края, реликтом некогда достаточно обширной этно-археологической общности, возникает вопрос о времени их появления в нынешних местах обитания, что хотя бы отчасти прояснит временные рамки миграции родственных кетам дене в Америку. В.Г.Волков в своей большой и обстоятельной статье «Древние миграции самодийцев и енисейцев в свете генетических данных», отмечая преобладание в генетике современных кетов и селькупов мужского субклада Q1a3 [19, с 80], описывает генетическую миграцию предков кетов на Средний Енисей из района Саян [там же, c 83] и датирует ее относительно поздним временем - эпохой существования самусьской и елунинской культур [там же, с 88] - т.е. II тысячелетием до н.э. Однако, существуют и более поздние датировки: «В литературе уже давно укрепилось мнение, что предки кетов относительно недавно мигрировали на Енисейский Север и формирование этого народа происходило на юге междуречья Оби и Енисея (Алексеенко 1994: 189). По мнению Е.А.Алексеенко, первые достоверно известные кетоязычные группы на рубеже эр проживали в горно-таежных районах Южной Сибири и Северо-Восточного Синьцзяна (Китай) (Алексеенко 1976: 180-184)» [там же, с 83], а «очагом первичной экспансии гаплогруппы Q1a3 являются территории, прилегающие к

Северной Индии, Афганистану и Ирану» [там же] - видимо, здесь речь идет все-же о мезолитических временах. В целом миграции предков кетов и селькупов (последние сменили свой язык на самодийский керамики) по версии В.Г. Волкова выглядит следующим образом:

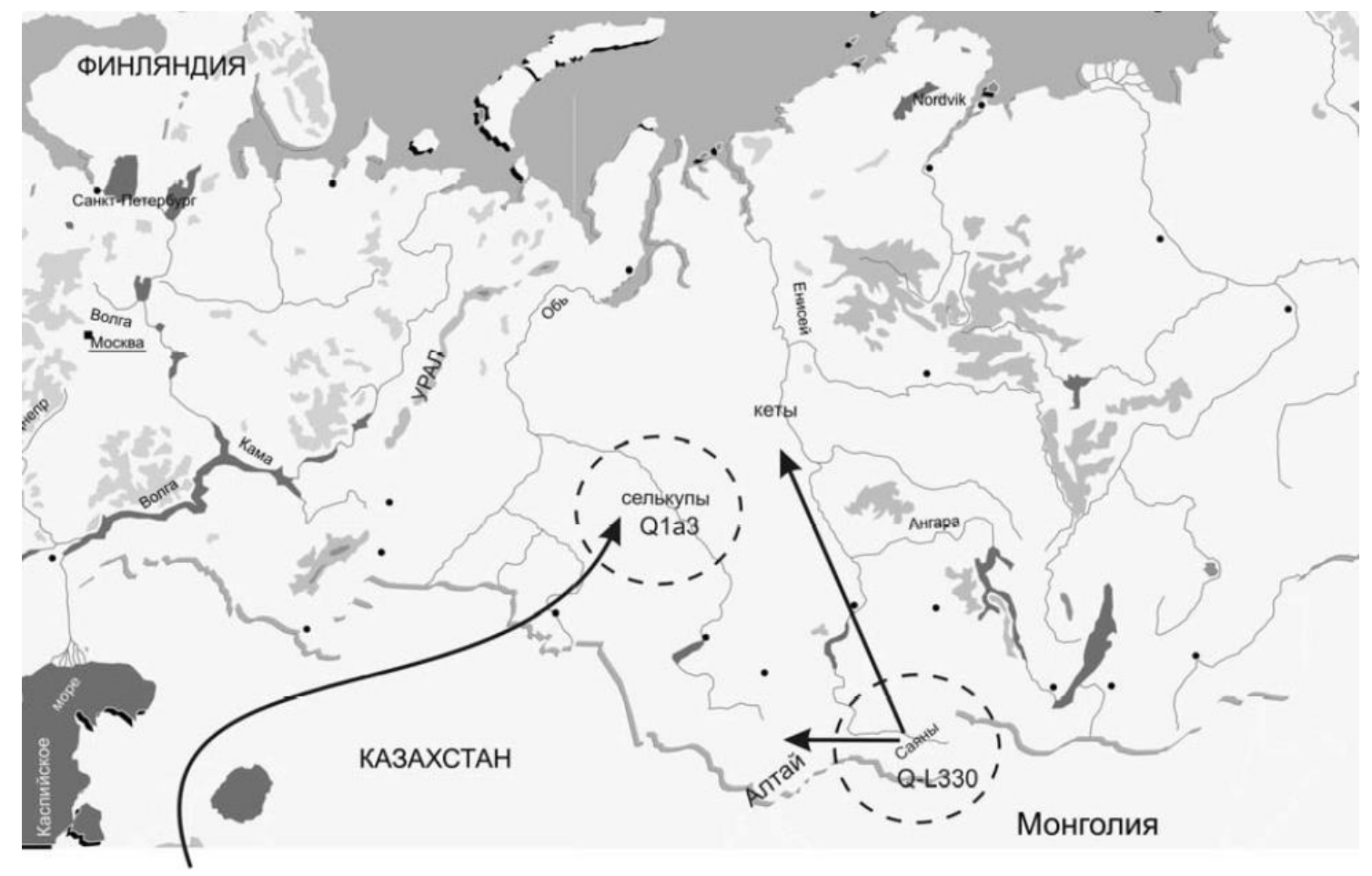

Рисунок 2 - Карта 2. Миграции древних енисейцев [там же, с 85].

Датировки миграций и географическое расположение денеязычных племен Америки вызывали даже появление гипотез о «непрерывной волне миграции» дене и эскимосов в III тысячелетии н.э. в рамках теории трех волн заселения Америки [20], тем более что присутствует определенная генетическая близость денеязычных групп и палеоэскимосов: «In summary, our model-free approach to analyze rare allele and haplotype sharing reveals that a fraction of Na-Dene Native Americans likely has a considerable proportion of Paleo-Eskimo ancestry, roughly from 10 to $30 \%$. Virtually no other Native Americans demonstrated the same signal in our analysis, despite a large number of populations and individuals investigated» [там же]. Также зафиксировано существенное родство (в пределах 22-24\%) племен атапасков с сибирскими популяциями, а древность этого родства оценивается в пределах 5000 лет до н.э. [там же]. 
Самым смелым выводом выше цитированной статьи является определение места палеоэскимосов в рамках сыалахской неолитической культуры и даже предположение об их денеязычии (либо принадлежности к денеенисейскому языковому континууму) [там же].То есть мы имеем первое научно обоснованную на генетических данных гипотезу о сибирской локализации дене (белькачинская и сыалахская культура). А если следовать дене-енисейской гипотезе и выводам В.Г.Волкова, то прародина их лежит глубже в Азии в сторону юго-запада. Известный лингвист В.В.Шеворошкин еще одну заметную группу америндов причислил к синокавказцам - а именно вакашско-салишские языки [22, p 85-86], сблизил с северокавказскими языками и датировал их отделение относительно недавним временем - III-II тысячелетиями до н.э. [там же, p 88]. Сопоставляя эту гипотезу с выводами Волкова о локализации кетов в Центральной Азии, то родственные кавказцам вакаши и салиши, возможно, были выхвачены мигрирующими дене-енисейцами из Прикаспия и прилегающих районов Центральной Азии, т.е. региона не столь удаленного от Кавказа.

$\begin{array}{ccc}\text { Однако, } & \text { недавние } \\ \text { прибайкальской } & \text { неолитической }\end{array}$ захоронений у поселка Локомотив в Иркутской области принесли сенсацию, которая показала неполноту гипотезы о дене-енисееязычном характере населения неолита Прибайкалья. Хотя у подавляющего числа мужских захоронений (особенно, поздних) оказалась уже надежно предсказуемая Y-гаплогруппа Q1a3, в некоторых из них, причем более ранних, была выявлена R1a1-M17. характерная для культур шнуровой керамики Восточной Европы. «Through SNaPshot multiplex PCR amplification, Y-chromosomal haplogroups were obtained from male individuals in the four cemeteries. Individuals from Lokomotiv and Shamanka II were found to possess haplogroups K, R1a1 and C3, and individuals from Ust'-Ida and Kurma XI were found to belong to haplogroups Q, K and unidentified SNP (L914)» [23, p III]. «Despite the low analytical success rate, Lokomotiv demonstrated the highest degree of heterogeneity in Y-chromosomal haplogroup distribution with four individuals belonging to haplogroup K-M9, two to haplogroup R1a1-M17 and one to haplogroup C3M217» [23, p 112]. «The two males belonging to haplogroup R1a1-M17 come from cluster 2 (LOK_1980.006 and LOK_1981.024.01), and the only male (LOK_1985.031.02) carrying C3-M217 Ychromosomal haplogroup comes from cluster 4» [там же].

Работа датирует 2 находки R1a1 в могильнике Локомотив ранним неолитом - т.е.
6000-4800 гг до н.э. (калибровано) [23, p II, 235]. Эти датировки можно сопоставить с датировками находок R1a1 на противоположном конце Евразии. Древнейшая ископаемая гаплогруппа R1a1-M17 прослежена у обитателей верховий Западной Двины в отрогах Валдайской возвышенности (Смоленская область) в эпоху неолита (3000- 4000 гг до н.э.) на стоянке Сертея VIII. А это - область устойчиво ассоциируема с индоевропейцами или их предками. Поэтому, вопрос о дене-енисейском характере байкальской шнуровой керамики не может быть однозначно решенным. И встает вопрос о родстве двух групп культур шнуровой керамики - западной и восточной.

Поскольку технологические рубежи влияния тех или иных древних центров отнюдь не всегда совпадают с культурно-лингвистическими, проблема прибайкальского неолита в настоящее время не может быть удовлетворительно разрешена. Прибайкалье не относится к зоне ранненеолитических культур Амура и Японских островов, в погребениях китойского времени (VI$\mathrm{V}$ тысячелетия до н.э.) керамическая посуда встречается редко [17, с 274]. Гребенчатая керамика встречается в китойской культуре [там же], есть и в глазковской культуре (стоянка УланХада [24, с 331]). В статье авторов [25] собраны и систематизированы определенные основания считать гребенчатые культуры Западной Евразии возможным признаком локализации носителей R1a1 в неолите. То есть наличие R1a1-M17 в некрополе Локомотив может быть признаком миграции носителей гребенчатой керамики далеко на Восток. В пользу этого говорит и наличие там же митохондриальной гаплогруппы $\mathrm{U} 5 \mathrm{a}$, древнейшие находки которой - в Европе [23]. Сумпаньинская культура, появление первых, еще мезолитических, памятников которой относится к VIII тысячелетию до н.э., и которая относится к традиции гребенчатой керамики [25, c 73] (последняя непрерывно разбавлялась влияниями технологии накольчатой керамики с юга $[17$, с 261]), могла оказать влияние на Прибайкалье. Некоторые исследования позволяют связать происхождение гребенчатой керамики Прибайкалья не с юго-восточным, а с западным направлением: «В настоящее время керамика с пунктирно-гребенчатым орнаментом зафиксирована в компрессионных слоях на территории Приангарья, Верхней Лены и Западного Забайкалья (Синицына, 1986; Зубков, 1982). Подобная керамика (с рядом региональных отличий) отмечена в поздненеолитических комплексах поселений Среднего Енисея (Савельев, 1989; Макаров, 2005)» [26, с 80]. Таким образом, возможно, что с гребенчатой 


\begin{tabular}{|c|c|c|c|c|c|c|}
\hline Impact Factor: & $\begin{array}{l}\text { ISRA (India) } \\
\text { ISI (Dubai, UAF } \\
\text { GIF (Australia) } \\
\text { JIF }\end{array}$ & $\begin{array}{l}=1.344 \\
=0.829 \\
=0.564 \\
=1.500\end{array}$ & $\begin{array}{l}\text { SIS (USA) } \\
\text { PИНЦ (Russia) } \\
\text { ESJI (KZ) } \\
\text { SJIF (Morocco) }\end{array}$ & $\begin{array}{l}=0.912 \\
=0.234 \\
=1.042 \\
=\mathbf{2 . 0 3 1}\end{array}$ & $\begin{array}{l}\text { ICV (Poland) } \\
\text { PIF (India) } \\
\text { IBI (India) }\end{array}$ & $\begin{array}{l}=6.630 \\
=1.940 \\
=4.260\end{array}$ \\
\hline
\end{tabular}

керамикой носители R1a1-M17 проникали в Прибайкалье с Запада.

Не так давно, авторы настоящей статьи [9] высказали осторожное предположение, что техника европейской шнуровой керамики могла прийти из ее восточного ареала. Текущие генетические данные показывают, что в какой-то момент неолита область распространения R1a1 могла занимать всю линию Валдай-АлтайБайкал. При этом древнейшей находкой R1a1 выглядит находка в Карелии (5500 до н.э.), затем - Локомотив (древнейшие R1a1-M17), затем Сертейская (тоже R1a1-M17). То есть вполне вероятно, что шнуровая техника могла прийти либо в процессе обратной миграции, либо технического обмена.

В прибайкальском неолите выделяются две линии развития - исаковско-серовская и собственно китойская - разумеется, возникает вопрос об их дифференциации и происхождении. Для китойской культуры подчеркивается доминирование именно сетчатого и шнурового орнамента: «Керамика встречается в захоронениях крайне редко. Это круглодонные сосуды, гладкостенные, а также украшенные сеткой-плетенкой и отпечатками шнура» [26]. То есть если группа носителей R1a1-M17 именно в Сибири могла перейти с гребенчатой техники производства керамики на шнуровую. В [9] авторы привели цитату, согласно которой в Прибайкалье именно в эпоху китойской культуры происходила депопуляция. «Of interest in this context is the fact that the analysis of Neolithic cemeteries of the Baikal region has suggested that a depopulation event occurred in that region during the 6th millennium BP (Mooder et al., 2006)». Известно, что в днепро-донецкой культуре (предшествует шнуровой керамике в Восточной Европе) была отмечена митогаплогруппа С, нехарактерная для Восточной Европы ни в бронзовый век, ни сейчас, но характерная для Сибири и Прибайкалья. То есть гипотеза о перемещении технологии шнуровой керамики с Востока на Запад (возможно с ее носителями) имеет право на существование. Возможно связи шли и косвенным путем, через Центральную Азию, и в культурном обмене могло принимать участи и дене-енисееязычное население.

\section{Conclusion}

Делать выводы еще преждевременно, но предварительный анализ новых данных и попытка сопрячь достижения генетики и археологии между показывает, что между западным и восточным ареалами шнуровой керамики могли быть как контакты, так и родство отдельных групп носителей.

\section{References:}

1. Rice, Prudence M (1999) "On the Origins of Pottery." Journal of Archaeological Method and Theory 6, no. 1, 1999: 1-54. Database on-line. Springerlink; accessed October 3, 2007.

2. (2004) Figure 3.3 from First Farmers: The Origins of Agricultural Societies by Peter Bellwood, 2004

3. Dzhal E, Malli Z, et al. (1998) Radiouglerodnaya khronologiya drevneyshikh neoliticheskikh kul'tur yuga Dal'nego Vostoka Rossii i Zabaykal'ya po rezul'tatam pryamogo datirovaniya keramiki metodom uskoritel'noy mass-spektrometrii // Paleoekologiya pleystotsena i kul'tury kamennogo veka Severnoy Azii i sopredel'nykh territoriy. Novosibirsk, 1998. -- Tom 2.

4. (1998) Radiouglerodnaya khronologiya drevnikh kul'tur kamennogo veka Severo-
Vostochnoy Azii. Vladivostok: TIG DVO RAN, 1998.

5. Higham, Charles (1996) The Bronze Age of Southeast Asia. Cambridge: Cambridge University Press, 1996.

6. Allan S (2005) The Formation of Chinese Civilization: An Archaeological Perspective. New Haven, CT, and Beijing: Yale University Press and New World Press, 2005.

7. Stark M (2005) Archaeology Of Asia. Blackwell Publishing, 2005.

8. Everstov SI (1999) Izobrazhenie na bereste i etnicheskaya identifikatsiya ymyyakhtakhskikh pamyatnikov Indigirki (v svete novykh arkheologicheskikh otkrytiy) //Arkheologiya Severo-Vostochnoy Azii. Astroarkheologiya. Paleometrologiya. - Novosibirsk: Nauka, 1999, pp. 40-64. 


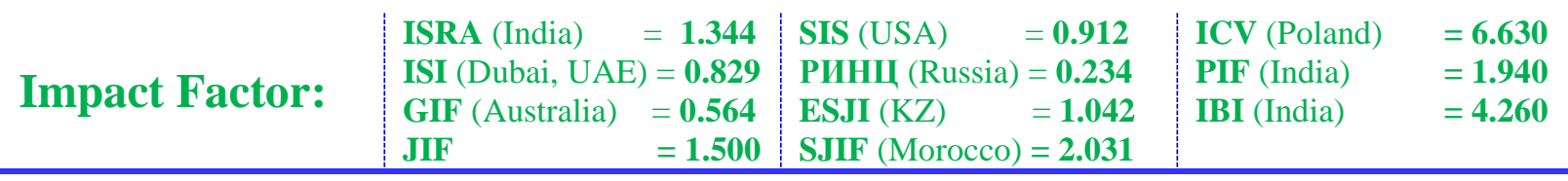

9. Alexander S. Semenov, Vladimir V. Bulat (2015) Possible North-Eastern Connections of the R1a1-populations of Corded Ware Culture According to the Archaeologic and Paleogenetic Data. Russian Journal of Biological Research. Vol. 5, Is. 3, pp. 173-194, 2015.

10. Hanihara K (1990) Dual Structure Model for the Formation of the Japanese Population//International Symposium on Japanese as a member of the Asian and Pacific population/Ed. Hanihara K. September 25 29, 1990, Kyoto.

11. Akulov AY (2007) K istorii voprosa o tsorpokkuru. Svyazi kul'tury aynov s kul'turoy Dzemon//Etnograficheskoe Obozrenie № 2, 2007.

12. (2010) Narody Severo-Vostochnoy Sibiri. Moscow, 2010.

13. Krauss Michael E (1965) "The protoAthapaskan-Eyak and the problem of Na-Dene, II: The morphology". International Journal of American Linguistics. 31 (1): 18-28. doi: $10.1086 / 464810$

14. Vajda Edward (2012) "Geography, Demography and Time Depth: Explaining how Dene-Yeniseian is possible." Presentation at the 2012 Dene-Yeniseian Workshop, Alaska Native Language Center, University of Alaska Fairbanks, March 24, 2012.

15. (2007) Sibir'. Atlas Aziatskoy Rossii. Moscow, 2007.

16. (2001) Zaselenie i osvoenie arkticheskikh territoriy. // Boyakova S.I. Osvoenie Arktiki i narody Severo-Vostoka Azii (XIX v. - 1917 g.). Novosibirsk: Nauka, 2001. - pp. 12-26.

17. (1996) Neolit Severnoy Evrazii. Moscow.
18. Fedoseeva SA (1999) Arkheologiya Yakutii i ee mesto $\mathrm{v}$ mirovoy nauke o proiskhozhdenii i evolyutsii chelovechestva: Ocherki po dopis'mennoy istorii Yakutii. Yakutsk, 1999.

19. Volkov VG (2013) Drevnie migratsii samodiytsev i eniseytsev v svete geneticheskikh dannykh. // Tomskiy zhurnal lingvisticheskikh i antropologicheskikh issledovaniy. 1(1) 2013.

20. Pavel Flegontov, et al. (2016) Na-Dene populations descend from the Paleo-Eskimo migration into America. doi: http://dx.doi.org/10.1101/074476.

21. (1999) Vsemirnaya istoriya. U istokov tsivilizatsii. Bronzovyy vek. Minsk,1999.

22. Shevoroshkin V (2008) On the Origin of Salish, Wakashnan, and North Caucasian Languages . International Journal of Modern Anthropology Int. J. Mod. Anthrop. 1: 1-121 (2008) Available: www.ata.org.tn (Accessed: 10.09.2016).

23. Nour Moussa (2015) Maternal and Paternal Polymorphisms in Prehistoric Siberian Populations of Lake Baikal. University of Alberta.

24. (1987) Epokha bronzy lesnoy polosy SSSR. Moscow.

25. Available: http://ejournal8.com/journals_n/1461227205.pd f (Accessed: 10.09.2016).

26. Dolganov VA, Goryunova OI, Novikov AG, Veber AV (2011) Kompleks s punktirnogrebenchatoy keramikoy i ego mesto $\mathrm{v}$ neolite Pribaykal'ya (po materialam mnogosloynogo poseleniya Sagan-Zaba II). // Drevnie kul'tury Mongolii i Baykal'skoy Sibiri. Materialy mezhdunarodnoy nauchnoy konferentsii (Irkutsk, 3-7 maya, 2011 g.) Vypusk 2. 